\title{
The effect of 'fibre-filler' (F-plan diet) on iron, zinc and calcium absorption in rats
}

\author{
BY SUSAN J. FAIRWEATHER-TAIT AND A. J. A. WRIGHT \\ AFRC Food Research Institute Norwich, Colney Lane, Norwich NR4 $7 U A$
}

(Received 22 February 1985 - Accepted 12 July 1985)

1. The availability of iron, zinc and calcium in a diet containing $400 \mathrm{~g}$ 'fibre-filler' (a mixture of bran, fruit and nuts, used in the F-plan diet)/ $\mathrm{kg}$ diet (HF diet) was measured by whole-body counting in rats, using ${ }^{59} \mathrm{Fe}$, ${ }^{65} \mathrm{Zn}$ and ${ }^{47} \mathrm{Ca}$ as extrinsic labels, and compared with a diet of similar mineral content but no 'fibre-filler' (LF diet). Absorption of $\mathrm{Fe}$ and $\mathrm{Ca}$ was significantly higher from the HF than from the LF diet but there was no difference in $\mathrm{Zn}$ availability between the two diets.

2. The ability of rats given LF or HF diets for 3 or $28 \mathrm{~d}$ to absorb $\mathrm{Fe}, \mathrm{Zn}$ and $\mathrm{Ca}$ was measured using ferrous sulphate, zinc chloride and calcium chloride in a cooked starch-sucrose $(1: 1 \mathrm{w} / \mathrm{w})$ paste, extrinsically-labelled with the appropriate isotope. There was no difference in Fe absorption between the HF- and LF-fed groups but both $\mathrm{Zn}$ and $\mathrm{Ca}$ absorption were higher in LF- than in HF-fed animals after 3 and $28 \mathrm{~d}$.

3. The mineral status of the animals given HF or LF diets for $28 \mathrm{~d}$ was examined, and there were no differences in blood haemoglobin, liver and bone $\mathrm{Zn}$ and plasma and bone $\mathrm{Ca}$ levels. The total liver $\mathrm{Fe}$ was significantly lower $(P<0.05)$ in the HF-fed animals.

4. It was concluded that 'fibre-filler' did not have an adverse effect on $\mathrm{Fe}, \mathrm{Zn}$ or $\mathrm{Ca}$ metabolism in rats although the long-term effect on $\mathrm{Fe}$ status warrants more detailed investigation. Further work is required to extend these studies to man.

'Fibre-filler' is eaten as part of the F-plan diet (Eyton, 1982) where it is recommended to replace one-fifth of the daily energy allowance. It comprises a mixture of bran, nuts and dried fruit and, together with a general increase in fruit, vegetables and beans, the F-plan diet aims to provide a slimming diet that is satisfying because of the high proportion of fibre. The effect of the substantial intake of dietary fibre (a minimum of $35 \mathrm{~g} / \mathrm{d}$ ) on mineral metabolism is not known but there is evidence that dietary fibre interferes with the absorption of some minerals (Ali et al. 1981). The following experiments in rats were designed to measure (a) iron, zinc and calcium availability in a diet containing $400 \mathrm{~g}$ 'fibre-filler' $/ \mathrm{kg}$ (HF diet); (b) $\mathrm{Fe}, \mathrm{Zn}$ and Ca absorption by rats given HF or low-fibre (LF) diets for $3 \mathrm{~d}$ or $28 \mathrm{~d}$ and (c) the effect of $28 \mathrm{~d}$ of HF or LF diets on $\mathrm{Fe}, \mathrm{Zn}$ and $\mathrm{Ca}$ status.

\section{MATERIALS AND METHODS \\ Animals and diets}

In all experiments male Wistar rats were used. They were housed individually in stainless-steel and plastic cages with grid bottoms and trained to meal-feed using a semi-synthetic control $\operatorname{diet}$ (Table 1). Throughout the experiments animals were regularly weighed and food intakes measured. Any animal that did not consume at least three-quarters of the labelled test meals was excluded from the experiment. The rats were returned to the control diet $a d l i b .4 \mathrm{~h}$ after the test meals.

The HF diet contained $400 \mathrm{~g}$ 'fibre-filler' $/ \mathrm{kg}$ diet, the remainder of the diet being made up of control diet. The $\mathrm{Fe}, \mathrm{Zn}$ and $\mathrm{Ca}$ contents of the $\mathrm{HF}$ diet were measured and the mineral mix for the LF diet adjusted so that the two diets contained levels of $\mathrm{Fe}, \mathrm{Zn}$ and $\mathrm{Ca}$ as nearly identical as possible. The phosphorus content was also adjusted so that the $\mathrm{Ca}: \mathbf{P}$ was $0 \cdot 5: 1$. 'Fibre-filler' was prepared by grinding all ingredients in a Moulinex coffee grinder, passing through a $1 \mathrm{~mm}$ sieve and mixing in a Hobart food mixer. The energy 
Table 1. Composition of control, high-fibre $(H F)$ and low-fibre $(L F)$ diets $(\mathrm{g} / \mathrm{kg})$

\begin{tabular}{lccc}
\hline Ingredient & Control & HF diet & LF diet \\
\hline Starch & 326 & 196 & 329 \\
Sucrose & 326 & 196 & 329 \\
Casein & 168 & 100 & 171 \\
Maize oil & 80 & 48 & 81 \\
Solkafloc & 40 & 24 & 40 \\
Mineral mix & $40^{*}$ & $24^{*}$ & $30 \dagger$ \\
Vitamin mix $\ddagger$ & 20 & 12 & 20 \\
'Fibre-filler’ & - & 400 & - \\
\hline
\end{tabular}

* Mineral mix (g/kg diet) for control and $\mathrm{HF}$ diets: $\mathrm{CaHPO}_{4} 13.0, \mathrm{CaCO}_{3} 8 \cdot 2, \mathrm{KCl} 7.03, \mathrm{Na}_{2} \mathrm{HPO}_{4} 7 \cdot 4$, $\mathrm{MgSO}_{4} . \mathrm{H}_{2} \mathrm{O} 4 \cdot 0, \mathrm{MnSO}_{4} \cdot \mathrm{H}_{2} \mathrm{O} 0 \cdot 18, \mathrm{ZnCO}_{3} 0 \cdot 10, \mathrm{FeSO}_{4} .7 \mathrm{H}_{2} \mathrm{O} 0 \cdot 144, \mathrm{CuSO}_{4} .5 \mathrm{H}_{2} \mathrm{O} 0 \cdot 023, \mathrm{~K}_{3} 0.001$.

$\dagger$ Mineral mix (g/kg diet) for LF diet: $\mathrm{CaCO}_{3} 11 \cdot 35, \mathrm{KCl} 7 \cdot 03, \mathrm{Na}_{2} \mathrm{HPO}_{4} 7 \cdot 4, \mathrm{MgSO}_{4}, \mathrm{H}_{2} \mathrm{O} 4 \cdot 0, \mathrm{MnSO}_{4} \cdot \mathrm{H}_{2} \mathrm{O}$

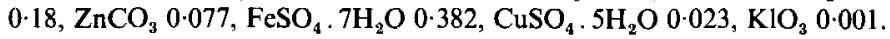

$\ddagger$ Vitamin mix (mg/kg diet): nicotinic acid 60, cyanocobalamin in mannitol (1/1000, Walton Pharmaceuticals, Walton-on Thames, Surrey) 50, calcium-D-pantothenate 40 , thiamin hydrochloride 10 , riboflavin 10 , pyridoxine 10, pteroylmonoglutamic acid 5, D-biotin 1, menadione 1, Rovimix E50 (Roche Products Ltd, Dunstable, Beds) 150, Rovimix A500 25, Rovimix $\mathrm{D}_{3} 50015$, choline bitartrate 1800 .

$\S$ 'Fibre-filler' (g/400 g): Branflakes (Kellogg's) 72.7, bran (Prewett's) 72.7, All-bran (Kellogg's) 72.7, almonds (ground; Whitworth's) 36.4, prunes (dried, destoned; Whitworth's) 36.4, apricots (dried, destoned; Whitworth's) 36.4, sultanas (Whitworth's) $72 \cdot 7$.

content of the diets was measured in a ballistic bomb calorimeter (Gallenkamp, London), dietary fibre of the 'fibre-filler' by the method of Englyst et al. (1982), phytate by a modification of the method of Tangkongchitr et al. (1981), $\mathrm{P}$ by the micromethod of the Association of Official Analytical Chemists (1980a), fructose by high-performance liquid chromatography, ascorbic acid by the microfluorometric method of the Association of Official Analytical Chemists (1980 $b$ ) and citric acid by a u.v. method (Boehringer Corporation, London).

\section{Expt 1}

Adult male Wistar rats, mean weight 333 (SEM 5.6) g, were randomly allocated to six groups of twenty animals. After an overnight fast they were given a test meal of $3 \mathrm{~g} \mathrm{HF}$ or LF diet, extrinsically-labelled with $0.5 \mu \mathrm{Ci}{ }^{59} \mathrm{Fe}, 1.0 \mu \mathrm{Ci}{ }^{65} \mathrm{Zn}$ or $1.0 \mu \mathrm{Ci}^{47} \mathrm{Ca}$ as follows: group $1 \mathrm{HF}, \mathrm{Fe}$; group $2 \mathrm{HF}, \mathrm{Zn}$; group $3 \mathrm{HF}, \mathrm{Ca}$; group $4 \mathrm{LF}, \mathrm{Fe}$; group $5 \mathrm{LF}, \mathrm{Zn}$; group 6 $\mathrm{LF}, \mathrm{Ca}$. The test meals were prepared by mixing the diet to a paste with distilled water containing isotope and leaving to stand for $1 \mathrm{~h}$ before feeding to the rats to ensure complete isotopic exchange.

The rats were individually counted for radioactivity in a whole-body counter (WBC) immediately after consuming the meal (designated day 0 of the experiment) and $7 \mathrm{~d}$ later (day 7), and retention expressed as percentage of day 0 after correcting for background and decay. Since the rate of turnover of $\mathrm{Fe}$ and $\mathrm{Ca}$ is very slow, day 7 retention approximates to true absorption. $\mathrm{Zn}$, however, is turned over more rapidly and day 7 retention only approximates to 'apparent' absorption. True absorption is somewhat higher, depending on the rate of turnover (Caprez \& Fairweather-Tait, 1982; Fairweather-Tait et al. 1985b). Since all groups were given the same diet (semi-synthetic control diet) after receiving the labelled test meal, any subsequent effect of diet on $\mathrm{Zn}$ turnover would be similar and differences in apparent absorption would be related to the previous diet or composition of the test meal.

$$
\text { Expt } 2
$$

Two groups of 120 rats with a 4-week age difference were used in an attempt to equalize their body-weights at the time of giving labelled meals. However, for logistical reasons it 
was necessary to complete the experiment before the second group of animals had quite reached the same weight as the first group. The older animals were allocated to six groups of twenty animals and three given the HF and three given the LF diet for $3 \mathrm{~d}$. On the 4th day they were given a meal of $5 \mathrm{~g}$ cooked starch-sucrose $(1: 1 \mathrm{w} / \mathrm{w})$ paste containing $\mathrm{Fe}$, $\mathrm{Zn}$ or $\mathrm{Ca}$ in the quantity equivalent to that found in $3 \mathrm{~g} \mathrm{HF}$ or $\mathrm{LF}$ diet, plus ${ }^{59} \mathrm{Fe},{ }^{65} \mathrm{Zn}$ or ${ }^{47} \mathrm{Ca}$ isotope. Each mineral was given to one group given the $\mathrm{HF}$ and one given the $\mathrm{LF}$ diet. Each rat in the $\mathrm{Fe}$ groups was given $200 \mu \mathrm{g} \mathrm{Fe}$ as $\mathrm{FeSO}_{4} \cdot 7 \mathrm{H}_{2} \mathrm{O}$ plus $1 \mu \mathrm{Ci}{ }^{59} \mathrm{Fe}$, the $\mathrm{Zn}$ groups $150 \mu \mathrm{g} \mathrm{Zn}$ as $\mathrm{ZnCl}_{2}$ plus $1 \mu \mathrm{Ci}^{\mathrm{B}}{ }^{5} \mathrm{Zn}$, and the $\mathrm{Ca}$ groups $15 \mathrm{mg} \mathrm{Ca}$ as $\mathrm{CaCl}_{2} \cdot 6 \mathrm{H}_{2} \mathrm{O}$ plus $1 \mu \mathrm{Ci}{ }^{47} \mathrm{Ca}$. Mineral absorption was measured as described previously.

The younger animals were also allocated to six groups of twenty animals and three given the HF and three given the LF diet for $28 \mathrm{~d}$, by which time they were approximately the same weight as the animals tested after $3 \mathrm{~d}$ on the diets. The same procedure was carried out as before to measure mineral absorption.

\section{Expt 3}

Twenty animals given the HF and twenty given the LF diet for $28 \mathrm{~d}$ (from Expt 2) were examined for $\mathrm{Fe}, \mathrm{Zn}$ and $\mathrm{Ca}$ status. They were anaesthetized under diethyl ether, and blood was removed by cardiac puncture and transferred into heparinized tubes. Blood haemoglobin $(\mathrm{Hb})$ was measured by the cyanomethaemoglobin method using Drabkin's solution (Cannan, 1958). The remainder of the blood was centrifuged and the plasma removed for Ca measurement by atomic absorption spectroscopy (AAS). Livers and right femurs were removed from the animals and freeze-dried. The livers were analysed for $\mathrm{Fe}$ and $\mathrm{Zn}$, and the bones for $\mathrm{Zn}$ and $\mathrm{Ca}$ by AAS.

\section{Mineral analysis}

Samples for $\mathrm{Fe}, \mathrm{Zn}$ and $\mathrm{Ca}$ analysis were ashed in silica crucibles at $480^{\circ}$ for $48 \mathrm{~h}$, the ash taken up in warm concentrated hydrochloric acid, made up to an appropriate volume with distilled water and measured by AAS on a PU9000 AAS (Pye Unicam, Cambridge) with background correction, using reference materials supplied by the National Bureau of Standards (Washington, USA).

\section{$W B C$}

Mineral retention from test meals was measured using ${ }^{59} \mathrm{Fe},{ }^{65} \mathrm{Zn}$ or ${ }^{47} \mathrm{Ca}$ gamma-isotopes (Amersham International plc, Amersham, Bucks) in a NE8112 small-animal counter (Nuclear Enterprises, Edinburgh) which has been described previously (Fairweather-Tait \& Wright, 1984). Counting efficiencies for ${ }^{59} \mathrm{Fe},{ }^{65} \mathrm{Zn}$ and ${ }^{47} \mathrm{Ca}$ were 50,25 and $45 \%$ respectively.

\section{Statistical analysis}

Differences between the HF and LF groups were tested for significance by unpaired $t$ tests. The relation between body-weight and mineral absorption was examined using the statistical package GENSTAT (Alvey et al. 1977) to calculate correlation coefficients. The effects of length of time and type of diet on mineral retention were examined by two-way analysis of variance (Snedecor \& Cochran, 1967).

\section{RESULTS}

The $\mathrm{Fe}, \mathrm{Zn}, \mathrm{Ca}$ and energy contents of 'fibre-filler', HF, LF and control diets are shown in Table 2, together with further analyses on 'fibre-filler' (phytate and fructose, ascorbic and citric acids). The high Fe content of 'fibre-filler' is mainly derived from fortification Fe added to Bran-flakes and All-bran (Kelloggs) during manufacture.

\section{Expt 1}

The mean rat weight on the day of the test meal was 333 (SEM 5.6) $\mathrm{g}(n$ 104). The percentage $\mathrm{Fe}, \mathrm{Zn}$ and $\mathrm{Ca}$ absorption from $3 \mathrm{~g}$ extrinsically-labelled $\mathrm{HF}$ or LF diet is given in 
Table 2. Analysis of 'fibre-filler', high-fibre $(H F)$, low-fibre $(L F)$ and control diets

\begin{tabular}{lcccc}
\hline & 'Fibre-filler' & HF diet & LF diet & Control diet \\
\hline Iron $(\mu \mathrm{g} / \mathrm{g})$ & $156 \cdot 6$ & $63 \cdot 7$ & $67 \cdot 6$ & $36 \cdot 6$ \\
Zinc $(\mu \mathrm{g} / \mathrm{g})$ & 36.8 & $56 \cdot 3$ & $56 \cdot 1$ & $66 \cdot 8$ \\
Calcium $(\mathrm{mg} / \mathrm{g})$ & $0 \cdot 84$ & 4.92 & $5 \cdot 27$ & $7 \cdot 02$ \\
Energy: $\mathrm{kJ} / \mathrm{g}$ & $20 \cdot 25$ & $20 \cdot 08$ & $19 \cdot 58$ & $19 \cdot 12$ \\
kcal $/ \mathrm{g}$ & 4.84 & $4 \cdot 80$ & 4.68 & 4.57 \\
Phytate $(\mathrm{g} / \mathrm{kg})$ & $7 \cdot 0$ & & & \\
Fructose $(\mathrm{g} / \mathrm{kg})$ & $95 \cdot 2$ & & & \\
Ascorbic acid $(\mathrm{mg} / \mathrm{kg})$ & $350 \cdot 0$ & & & \\
Citric acid $(\mathrm{mg} / \mathrm{kg})$ & $571 \cdot 5$ & & \\
\hline \hline
\end{tabular}

Table 3. Percentage iron, zinc and calcium absorption from $3 \mathrm{~g}$ extrinsically-labelled high-fibre $(H F)$ or low-fibre $(L F)$ diets $\dagger$

(Mean values with their standard errors)

\begin{tabular}{|c|c|c|c|c|c|c|}
\hline \multirow[b]{2}{*}{ Mineral } & \multicolumn{3}{|c|}{ HF diet } & \multicolumn{3}{|c|}{ LF diet } \\
\hline & $n$ & $\begin{array}{l}\text { Percentage } \\
\text { absorption }\end{array}$ & SEM & $n$ & $\begin{array}{l}\text { Percentage } \\
\text { absorption }\end{array}$ & SEM \\
\hline $\mathrm{Fe}$ & 16 & 34.9 & $2 \cdot 2$ & 17 & $25 \cdot 5^{* *}$ & 1.7 \\
\hline $\mathrm{Zn}$ & 18 & $16 \cdot 1$ & 0.8 & 18 & 17.9 & 0.9 \\
\hline $\mathrm{Ca}$ & 15 & $60 \cdot 2$ & 2.6 & 15 & $44 \cdot 4^{* * * *}$ & 2.5 \\
\hline
\end{tabular}

Mean values for $\mathrm{LF}$ diet were significantly different from those for HF diet: ${ }^{* *} P<0.01,{ }^{* * *} P<0.001$.

$\dagger$ For details of diets, see Table 1.

Table 3. Absorption of both $\mathrm{Fe}(P<0.01)$ and $\mathrm{Ca}(P<0.001)$ was significantly higher from the HF than from the LF diet, but there was no difference in $\mathrm{Zn}$ availability between the two diets.

Expt 2

The mean rat weight on the day of the test meal was 260 (SEM 2.3) $\mathrm{g}(n$ 99) in the groups tested after $3 \mathrm{~d}$ on the HF or LF diet, and 218 (SEM 2.6) $\mathrm{g}(n$ 111) in those tested after $28 \mathrm{~d}$ on the HF or LF diet. Because of the possibility of an effect of body-weight on mineral absorption, for example with $\mathrm{Fe}$ in young rapidly-growing rats (Fairweather-Tait \& Wright, 1985), the relation between body-weight and mineral absorption was examined, but no significant correlation found.

The percentage mineral absorption by rats previously given HF or LF diet for 3 or $28 \mathrm{~d}$ from a solution of $\mathrm{Fe}, \mathrm{Zn}$ or $\mathrm{Ca}$ given in starch-sucrose paste is shown in Fig. 1. When tested by two-way analysis of variance, the results demonstrate an effect of length of time on the HF or LF diet on Fe absorption (which fell with time) but no effect of diet. $\mathrm{Zn}$ and $\mathrm{Ca}$ were both significantly affected by length of time on the HF or LF diet and by the diet itself. $\mathrm{Zn}$ absorption fell with time, but was higher in the LF-fed animals at both time periods. Ca absorption was also higher in the LF-fed animals, but in contrast to $\mathrm{Zn}$ it increased with time.

\section{Expt 3}

The blood $\mathrm{Hb}$ and liver Fe levels are shown in Table 4. There were no differences in blood $\mathrm{Hb}$ or liver Fe concentration, but total liver Fe was significantly lower $(P<0 \cdot 05)$ in the $\mathrm{HF}$ 


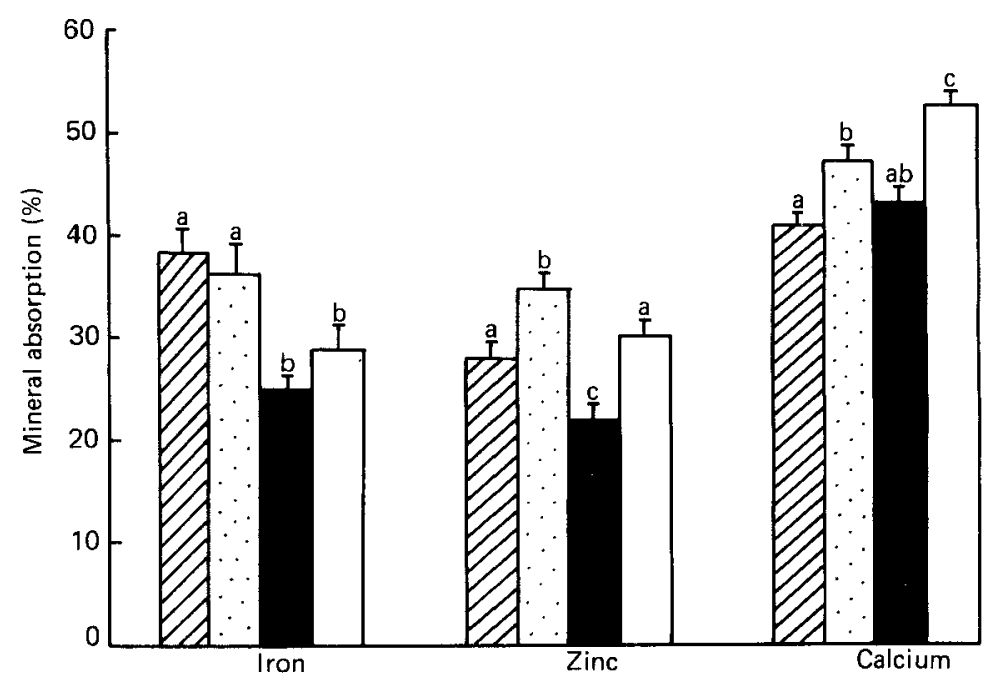

Fig. 1. Percentage of mineral absorbed by rats given $400 \mathrm{~g}$ 'fibre filler'/kg (HF) or low-fibre (LF) diets for 3 or $28 \mathrm{~d}$ : 四, HF $3 \mathrm{~d}$; 圈, LF $3 \mathrm{~d}$; $\square$, HF $28 \mathrm{~d}$; $\square$, LF $28 \mathrm{~d}$. ${ }^{\mathrm{a}, \mathrm{b}, \mathrm{c}}$ For each mineral, values with the same superscript letters were not significantly different. Values are group means with their standard errors represented by vertical bars.

Table 4. Blood haemoglobin $(H b)$, plasma calcium, liver iron and zinc, and femur $\mathrm{Zn}$ and $C a$ in rats given high-fibre $(H F)$ or low-fibre (LF) diets for $28 d$

(Mean values with their standard errors for twenty rats per group)

\begin{tabular}{|c|c|c|c|c|}
\hline & \multicolumn{2}{|c|}{$\mathrm{HF}$ diet } & \multicolumn{2}{|c|}{ LF diet } \\
\hline & Mean & SEM & Mean & SEM \\
\hline $\mathrm{Hb}(\mathrm{g} / \mathrm{l})$ & $118 \cdot 0$ & $2 \cdot 3$ & $118 \cdot 0$ & $1 \cdot 5$ \\
\hline Plasma Ca $(\mu \mathrm{g} / \mathrm{ml})$ & $103 \cdot 0$ & $2 \cdot 45$ & $108 \cdot 8$ & $1 \cdot 64$ \\
\hline Liver $\mathrm{Fe}: \mu \mathrm{g} / \mathrm{g}$ dry wt & $218 \cdot 2$ & $7 \cdot 2$ & 237.9 & $9 \cdot 8$ \\
\hline Total mg & 0.873 & 0.031 & $1.029 *$ & 0.054 \\
\hline Liver $\mathrm{Zn}: \mu \mathrm{g} / \mathrm{g}$ dry wt & $84 \cdot 6$ & $1 \cdot 16$ & $82 \cdot 4$ & 1.68 \\
\hline Total $\mu \mathrm{g}$ & $338 \cdot 7$ & $8 \cdot 91$ & $355 \cdot 8$ & $12 \cdot 52$ \\
\hline Bone $\mathrm{Zn}: \mu \mathrm{g} / \mathrm{g}$ dry wt & $191 \cdot 7$ & $3 \cdot 35$ & 195.9 & $2 \cdot 46$ \\
\hline Total $\mu \mathrm{g}$ in femur & $88 \cdot 2$ & $2 \cdot 24$ & $93 \cdot 2$ & $2 \cdot 40$ \\
\hline Bone $\mathrm{Ca}: \mathrm{mg} / \mathrm{g}$ dry wt & $225 \cdot 4$ & $3 \cdot 89$ & $230 \cdot 7$ & $4 \cdot 41$ \\
\hline Total $\mathrm{mg}$ in femur & $106 \cdot 1$ & $2 \cdot 67$ & $106 \cdot 5$ & $2 \cdot 47$ \\
\hline
\end{tabular}

Mean value for LF diet was significantly different from that for $\mathrm{HF}$ diet: $* P<0 \cdot 05$.

group. There were no differences in plasma $\mathrm{Ca}$, liver $\mathrm{Zn}$, bone $\mathrm{Zn}$ and bone $\mathrm{Ca}$ between the two groups, also shown in Table 4.

\section{DISCUSSION}

There are a number of reports in the literature suggesting that some forms of dietary fibre reduce mineral absorption; other substances in fibre-rich foods have also been implicated as interfering with mineral availability, such as phytate. On the other hand, some studies show that dietary fibre has no effect on mineral metabolism or nutritional status. Therefore 
it is impossible to predict from the literature the short- and long-term effects of a high-fibre diet of mixed origin (i.e. cereals, nuts and fruit) on mineral status or on the ability of the body to absorb minerals. The F-plan diet (Eyton, 1982) has received much publicity and millions of copies of the book have been sold throughout the world. Thus, 'fibre-filler' is being consumed by large numbers of people, and the metabolic consequences of such a radical increase in fibre intake is an area of great concern to nutritionists and the medical profession.

Most studies indicate that dietary fibre is not a major determinant of $\mathrm{Fe}$ availability but that some types of fibre interact with Fe to reduce availability. Bran, but not pectin or cellulose, has a modest effect on Fe availability in human subjects; Fe absorption was reduced from 2.26 to $1.07 \%$ when $5 \mathrm{~g}$ bran was added to an $80 \mathrm{~g}$ muffin (Cook et al. 1983). A similar effect was shown with $12 \mathrm{~g}$ bran added to a light meal; absorption decreased from 3.46 to $1.69 \%$ or, in the presence of $100 \mathrm{mg}$ ascorbic acid, from 9.29 to $3.89 \%$ (Simpson et al. 1981).

The absorption of $\mathrm{Fe}$ (when measured from $3 \mathrm{~g}$ of a diet extrinsically-labelled with ${ }^{59} \mathrm{Fe}$ ) was greater from the HF (34.9 (SEM 2.2$) \%$ ) than from the LF diet $(25.5(\operatorname{SeM} 1.7) \%$ ). Thus it may be concluded that 'fibre-filler', the major source of Fe in the HF diet, contains Fe which is relatively well-absorbed. The relatively high content of fructose $(95 \mathrm{~g} / \mathrm{kg}$ 'fibre-filler'), ascorbic acid $(350 \mathrm{mg} / \mathrm{kg})$ and citric acid $(571.5 \mathrm{mg} / \mathrm{kg})$ derived from the fruit in the 'fibre-filler' may be responsible for the higher absorption of Fe. These enhancing factors obviously had a more potent effect than the reputedly inhibitory effect of phytate $(7 \cdot 0 \mathrm{~g} / \mathrm{kg})$. In fact, when the detrimental action of bran on Fe absorption was investigated in detail, it was found that removal of phytate did not alter the inhibitory effect on Fe absorption, and that the soluble, phosphate-rich fraction of bran was more inhibitory than the insoluble, high-fibre fraction (Simpson et al. 1981). Furthermore, fibre in fruit and vegetables has no effect on Fe balance in humans (Kelsay et al. 1979). It is therefore not unduly surprising that the $\mathrm{Fe}$ in 'fibre-filler' is quite well absorbed.

When the capacity to absorb $\mathrm{Fe}$ was examined in rats that had previously been on the $\mathrm{HF}$ or LF diet for 3 or $28 \mathrm{~d}$, using $\mathrm{FeSO}_{4}$ in a starch-sucrose paste, there were no significant differences between the two dietary groups. However, Fe absorption was higher in rats given both the HF or LF diet for $3 \mathrm{~d}$ than for $28 \mathrm{~d}$. The most likely explanation for this finding is that the control diet fed to the animals before the investigation contained little more than half the Fe of the HF and LF diets. Thus during the $28 \mathrm{~d}$ of feeding these experimental diets the animals were able to increase Fe stores and improve Fe status, thereby reducing Fe requirements, resulting in a fall in absorptive capacity for Fe (Heinrich, 1970). The reduction in total liver Fe in the HF-diet group $(P<0.05)$ does not logically follow the fact that Fe was better absorbed from the HF diet. It may, of course, be an artifact compounded by multiplying the liver $\mathrm{Fe}$ concentration (slightly lower in the HF group, but not significantly different) by dry liver weight (again slightly, but not significantly lower in the HF group). Alternatively, the explanation may be that the animals had gradually adapted to the HF diet, perhaps by altering their 'mucosal setting', and absorbed less Fe over time, thus decreasing Fe storage in the liver. It has been shown that there is a profound influence of dietary $\mathrm{Fe}$ levels on subsequent $\mathrm{Fe}$ absorption, probably mediated through the intestinal mucosal cells (Fairweather-Tait et al. 1985a). Thus, if the rats are presented with a more available source of $\mathrm{Fe}$, in the form of 'fibre-filler' containing enhancing factors (fructose, ascorbic acid and citric acid), then subsequent capacity of the mucosal cells to take up $\mathrm{Fe}$ from the lumen and transfer it to the body might be depressed (in order to maintain $\mathrm{Fe}$ balance and prevent Fe overload), since there appears to be no homeostatic mechanism for excreting $\mathrm{Fe}$.

The effect of fibre on $\mathrm{Zn}$ availability is less controversial than that of Fe. Most studies 
show that bran, particularly hemicellulose, decreases $\mathrm{Zn}$ balance (Kelsay, 1981). However, it is interesting to note that with $\mathrm{Zn}$ there is some evidence that the body is able to adapt to low- $\mathrm{Zn}$ intakes or diets containing $\mathrm{Zn}$ of low availability. One study showed that human subjects given large amounts of unleavened wholemeal bread initially went into negative $\mathrm{Zn}$ balance, but after $50 \mathrm{~d} \mathrm{Zn}$ balances became positive (Campbell et al. 1976). Since Kies et al. (1979) found that hemicellulose resulted in negative $\mathrm{Zn}$ balances in adult men which remained negative for at least $14 \mathrm{~d}$ it is clear that the time taken for this adaptive process to occur is weeks rather than days. The 28-d feeding period in Expt 2 is about $5 \%$ of the life-span of the rat, which is a relatively long time and should be large enough to demonstrate whether adaptation had occurred or not. However, the possibility that changes in mineral metabolism would occur with even longer-term feeding cannot be discounted.

There was no difference in $\mathrm{Zn}$ availability from the HF and LF diets. However, animals previously given the HF diet absorbed significantly less $\mathrm{Zn}$ from the $\mathrm{Zn}$ salt than those given the LF diet, after feeding the diet for 3 or $28 \mathrm{~d}$. As in the case of Fe, absorption from both groups was lower after $28 \mathrm{~d}$ than after $3 \mathrm{~d}$, although the difference was less marked than with $\mathrm{Fe}$. This fall cannot be explained in terms of $\mathrm{Zn}$ concentration in the diet because unlike the case with $\mathrm{Fe}$ it was lower in the HF and LF diets than in the control diet. There are at least two possible explanations for this observation: (a) that the $\mathrm{Zn}$ status, or some other nutritional index, of animals on the HF and LF diets for $28 \mathrm{~d}$ was different from those fed for $3 \mathrm{~d}$, or (b) that there is some component in the HF diet that modifies the ability of the intestine to absorb $\mathrm{Zn}$, or a combination of (a) and (b). Commercial rat pellets (CRM; Labsure) containing $99 \mathrm{~g}$ dietary fibre $/ \mathrm{kg}$ have been shown to increase mucosal cell proliferation compared with a semi-synthetic diet containing $40 \mathrm{~g}$ cellulose (Solkafloc) $/ \mathrm{kg}$ as the source of dietary fibre (Southon et al. 1985), and similar effects have been observed with guar gum (Johnson et al. 1984). From these results it has been postulated that the increase in cellular proliferation results in a higher proportion of immature cells in the absorptive surface of the intestine, and that uptake and transport of nutrients is consequently reduced in line with decreased maturity of the cells, reduced enzyme levels, etc. Since there was no evidence of any difference between the HF and LF groups in the indices used to assess $\mathrm{Zn}$ status, i.e. liver and bone $\mathrm{Zn}$, after $28 \mathrm{~d}$, it appears that 'fibre-filler' does not adversely affect $\mathrm{Zn}$ status. The HF group showed a consistently lower ability to absorb $\mathrm{Zn}$ than the LF group after 3 and $28 \mathrm{~d}$, which negates the hypothesis that animals can adapt over time, and agrees with findings of Bagheri \& Guéguen (1982).

$\mathrm{Ca}$ balance has been shown to be adversely affected by cereal and fruit fibre. Cummings et al. (1979) found that the addition of $31 \mathrm{~g}$ wheat fibre to the daily diet for 3 weeks resulted in subjects going into negative $\mathrm{Ca}$ balance. Urinary $\mathrm{Ca}$ increased which led the authors to conclude that the dietary fibre was impairing $\mathrm{Ca}$ absorption. A similar effect was shown with a cellulose-apple supplement, but in addition a fall in plasma $\mathrm{Ca}$ was demonstrated (Ismail-Beigi et al. 1977). Results from Expt 1 showed that more Ca was absorbed from the HF than the LF diet, yet the ability of the intestine to absorb $\mathrm{Ca}$ from a Ca salt was greater in animals previously given the LF diet. As in the case of $\mathrm{Zn}$ this may be due to a modification by the HF diet of the intestine's capacity to absorb $\mathrm{Ca}$, or the reduction in $\mathrm{Ca}$ absorption may be a direct result of enhanced $\mathrm{Ca}$ absorption on the HF diet. The latter explanation is unlikely since the plasma and bone $\mathrm{Ca}$ levels in the HF and LF groups were similar after $28 \mathrm{~d}$ on the different diets, thus indicating no change in $\mathrm{Ca}$ status, i.e. the correct maintenance of $\mathrm{Ca}$ homeostasis.

In conclusion, it appears that 'fibre-filler' has no major adverse effect on $\mathrm{Fe}, \mathrm{Zn}$ or $\mathrm{Ca}$ metabolism in the rat. It appears to modify the capacity of the intestine to absorb minerals in that animals given a HF diet have a reduced ability to absorb $\mathrm{Zn}$ and $\mathrm{Ca}$ but their status is unchanged after $28 \mathrm{~d}$ on the diet. There is no sign of adaptation to the diet in terms of 
alterations in mineral absorption over the time-period studied $(5 \%$ of the life-span of the rat). Further work is required to assess the implications of extended periods of consuming 'fibre-filler', in particular more sensitive measurements of change in Fe status. If these results are applicable to man the hypothesis that high intakes of fibre in the F-plan diet have a detrimental effect on $\mathrm{Fe}, \mathrm{Zn}$ and $\mathrm{Ca}$ status is not substantiated.

This work was partially supported by a research grant from the International Foundation for the Promotion of Nutrition Research and Nutrition Education, Zug, Switzerland.

The authors thank Mr J. Tozer, Mrs Z. Piper and Miss L. Symss for technical assistance, Mrs J. Cooke for help with the animals, Miss R. Girdlestone for AAS analysis and $\mathrm{Mr}$ R. Faulks for fibre, fructose and ascorbic acid determinations.

\section{REFERENCES}

Ali, R., Staub, H., Coccodrilli, G. \& Schanbacher, L. (1981). Journal of Agricultural Food Chemistry 29, $465-472$. Alvey, N. G., Banfield, C. F., Baxter, R. I., Gower, J. C., Krzanowski, W. J., Lane, P. W., Leech, P. W., Nelder, J. A., Payne, R. W., Phelps, K. M., Rogers, C. E., Ross, G. J. S., Simpson, H. R., Todd, A. D., Tunnicliffe-Wilson, G., Wedderburn, R. W. M., White, R. P. \& Wilkinson, G. N. (1977). The GENSTAT Manual. Oxford: Rothamstead Experimental Station, Numerical Algorithms Group Ltd.

Association of Official Analytical Chemists (1980a). Methods of Analysis 13, 39.

Association of Official Analytical Chemists (1980 b). Methods of Analysis 13, 746-747.

Bagheri, S. M. \& Guéguen, L. (1982). Journal of Nutrition 112, 2047-2051.

Campbell, B. J., Reinhold, J. G., Cannell, J. J. \& Nourmand, I. (1976). Pahlavi Medical Journal 7, 1-17.

Cannan, R. K. (1958). Clinical Chemistry 4, 246-251.

Caprez, A. \& Fairweather-Tait, S. J. (1982). British Journal of Nutrition 48, 467-475.

Cook, J. D., Noble, N. L., Morck, T. A., Lynch, S. R. \& Petersburg, S. J. (1983). Gastroenterology 85, $1354-1358$.

Cummings, J. H., Hill, M. J., Jivraj, T., Houston, H., Branch, W. J. \& Jenkins, D. J. A. (1979). American Journal of Clinical Nutrition 32, 2086-2093.

Englyst, H., Wiggins, H. S. \& Cummings, J. H. (1982). Analyst 107, 307-318.

Eyton, A. (1982). F-Plan Diet. Harmondsworth, Middlesex: Penguin Books Ltd.

Fairweather-Tait, S. J., Swindell, T. E. \& Wright, A. J. A. (1985a) British Journal of Nutrition 54, 79-86.

Fairweather-Tait, S. J. \& Wright, A. J. A. (1984). British Journal of Nutrition 51, 185-191.

Fairweather-Tait, S. J. \& Wright, A. J. A. (1985). British Journal of Nutrition 53, 193-197.

Fairweather-Tait, S. J., Wright, A. J.A., Cooke, J. \& Franklin, J. (1985b). British Journal of Nutrition 54, $401-413$.

Heinrich, H. C. (1970). Iron Deficiency: Pathogenesis, Clinical Aspects, Therapy, pp. 213-296 [L. Hallberg, H.-G. Harweth and A. Vanotti, editors]. New York: Academic Press.

Ismail-Beigi, F., Reinhold, J. G., Faraji, B. \& Abadi, P. (1977). Journal of Nutrition 107, 510-518.

Johnson, I. T., Gee, J. M. \& Mahoney, R. R. (1984). British Journal of Nutrition 52, 477-487.

Kelsay, J. L. (1981). Cereal Chemistry 58, 2-5.

Kelsay, J. L., Behall, K. M. \& Pratter, E. S. (1979). American Journal of Clinical Nutrition 32, $1876-1880$.

Kies, C., Fox, H. M. \& Beshgetoor, D. (1979). General Chemistry 56, 133-136.

Simpson, K. M., Morris, E. R. \& Cook, J. D. (1981). American Journal of Clinical Nutrition 34, $1469-1478$.

Snedecor, G. W. \& Cochran, W. G. (1967). Statistical Methods, 6th ed. Ames, Iowa: Iowa State University Press. Southon, S., Livesey, G., Gee, J. M. \& Johnson, 1. T. (1985). British Journal of Nutrition 53, 87-95.

Tangkongchitr, V., Seib, P. A. \& Hoseney, R. C. (1981). Cereal Chemistry 58, 226-228. 